\title{
Phytoextraction of Metal Contaminants by Typha angustifolia: Interaction of Lead and Cadmium in Soil-Water Microcosms
}

\author{
Thanawan Panich-Pat $^{1 *}$, Suchart Upatham ${ }^{2}$, Prayad Pokethitiyook ${ }^{3}$, Maleeya Kruatrachue ${ }^{3}$, \\ Guy R. Lanza ${ }^{4}$
}

${ }^{1}$ Faculty of Liberal Arts and Science, Kasetsart University, Nakhon Pathom, Thailand; ${ }^{2}$ Faculty of Science, Burapha University, Chonburi, Thailand; ${ }^{3}$ Faculty of Science, Mahidol University, Bangkok, Thailand; ${ }^{4}$ Environmental Science Program, University of Massachusetts, Amherst, USA.

Email: faastwp@ku.ac.th

Received September $6^{\text {th }}, 2010$; revised October $16^{\text {th }}, 2010$; accepted October $20^{\text {th }}, 2010$.

\begin{abstract}
A greenhouse study was conducted on phytoextraction and accumulation of lead $(\mathrm{Pb})$ and cadmium $(\mathrm{Cd})$ from contaminated soil - water microcosms by the narrow-leaved cattail, Typha angustifolia. The plants were grown in sandy loam soil containing 1,666 and $38.5 \mathrm{mg} / \mathrm{L}$ of $\mathrm{Pb}\left(\mathrm{NO}_{3}\right)_{2}$ and $\mathrm{Cd}\left(\mathrm{NO}_{3}\right)_{2}$ respectively. The trends of lead and cadmium by $\mathrm{T}$. angustifolia for all soil - water microcosms suggested interaction effects as decreased soil lead concentrations and increased water cadmium concentrations over time. T. angustifolia expressed trends as increased biomass in all contaminated shoots and roots examined. Cadmium uptake in shoot and root biomass slightly decreased when lead was initially added to the soil but cadmium uptake in root biomass increased after 30 days. Data suggested an interaction between lead and cadmium and that lead uptake was inhibited when cadmium was present.
\end{abstract}

Keywords: Phytoextraction, Contaminant Interaction, Lead, Cadmium, Microcosm, Typha angustifolia

\section{Introduction}

Lead and cadmium are elements that are highly toxic to plants [1]. Both heavy metals are capable of interacting in biological systems and are persistent contaminants that can change their speciation, but do not biodegrade. Cadmium is the heavy metal of greatest concern in most agricultural soils. It is loosely held by soil constituents and is readily available to plant roots and transported through the xylem to the vegetative and reproductive organs, negatively affecting the crops [2]. In general, broadleaf plants such as lettuce and swiss chard accumulate more cadmium than grasses. Plant leaves and stems can also accumulate more than seeds. Nevertheless, lead and cadmium can be toxic and inhibit DNA synthesis, mitosis, cell division and germination [3]. Iqbal et al. [3] also investigated the effect of lead and cadmium individually and in combination on the germination and seedling growth of Leucaena leucocephala and Delonix regia. They found reduced germination and seedling growth, and that both species showed more tolerance to lead than cadmium. Kastori et al. [4] found that the treatment of sunflower plants with lead diminished the concentrations of chlorophylls and carotenes, while Larsson et al. [5] observed a reduction in the chlorophyll concentrations of plants exposed to cadmium. Mohan and Hosetti [6] suggested that both cadmium and lead drastically depressed catalase activity but stimulated peroxidase activity. They reported that the interaction between lead and cadmium on growth of other plants e.g., the root of Juncus acustus, was strongly inhibited by lead nitrate. Iqbal et al. [3] reported that the toxicity of lead and cadmium to young trees of Fagus silvatica is higher when both are combined. Other reports indicated that these two metals can bind to the cell wall, thus weakening their toxic effects to plants [7].

Phytoremediation is the use of plants to remove contaminants from soil, water and air. One promising phytoremediation process is the phytoextraction of heavy metal contaminants from soil. Typha spp has been studied for their ability to phytoextract metals from soil, but most research to date reports the phytoextraction of individual heavy metal contaminants rather than mixtures of metals that commonly occur at contaminated sites. This 
study examined the interaction of lead and cadmium during metal phytoextraction from soil-water microcosms by Typha angustifolia.

\section{Materials and Methods}

\subsection{Plant Microcosm}

T. angustifolia were obtained from New England Wetland Plant Company and planted in plastic bucket microcosms (50 cm height, $30 \mathrm{~cm}$ diameter) containing 10 $\mathrm{kg}$ of sandy loam soil, collected from Orchard Hill, Massachusetts, USA. Sixteen buckets of microcosms were prepared, each with 2 plants in $10 \mathrm{~kg}$ of soil with a 5 liter layer of surface water. The microcosms were maintained in a greenhouse at a temperature of $24 \pm 1{ }^{\circ} \mathrm{C}$ under a full spectrum of $400 \mathrm{~W}$ light source providing a 16 hour per day photoperiod. The plants in microcosms were allowed to grow for 30 days until the plants reached an average height of $30 \mathrm{~cm}$ and then received the heavy metal treatments.

\subsection{Soil Characterization}

One to three gram samples of soil were dried overnight in an oven at $105^{\circ} \mathrm{C}$. Soil samples were sieved through $2 \mathrm{~mm}$ and $0.5 \mathrm{~mm}$ screen, thoroughly mixed and ground in a mortar and pestle to obtain a uniform texture. Soil subsamples of 0.1-0.3 g were digested in $3 \mathrm{ml}$ of concentrated $\mathrm{HNO}_{3}$ using microwave digestion (CEM model MDS - 2100) for approximately 30 minutes. Samples were then evaporated to near dryness, filtered, and adjusted to a volume of $25 \mathrm{ml}$ in distilled water. Soil samples were analyzed for lead and cadmium concentration before and after the addition of lead and cadmium mixtures using Flame Atomic Absorption Spectrophotometer (FAAS), Graphite Furnace Atomic Absorption Spectrophotometer (GFAAS), and Hydride Generation (HG).

\subsection{Preparation of Stock Solutions and Application of Lead and Cadmium}

Lead as $\mathrm{Pb}\left(\mathrm{NO}_{3}\right)_{2}$ and cadmium as $\mathrm{Cd}\left(\mathrm{NO}_{3}\right)_{2}$ were dissolved in distilled water to prepare a stock solutions for treatment groups at concentrations of $10,000 \mathrm{mg} / \mathrm{L}$ and $1,000 \mathrm{mg} / \mathrm{L}$, respectively. One liter of the lead stock solution was added to $5 \mathrm{~L}$ of distilled water to obtain a concentration of $1,666 \mathrm{mg} / \mathrm{L}$ for application to each microcosm. Two hundred $\mathrm{ml}$ of the cadmium stock solution was added into $5 \mathrm{~L}$ to obtain a concentration of 38.5 $\mathrm{mg} / \mathrm{L}$. The sixteen microcosms were randomly divided into 4 treatment groups, each group with four replicates as follows:

Group 1 served as the controls (no additions of lead and cadmium),

Group 2 received cadmium solutions at a concentration of $38.5 \mathrm{mg} / \mathrm{L}$,

Group 3 received lead solutions at a concentration of $1,666 \mathrm{mg} / \mathrm{L}$,

Group 4 received a mixture of lead at $1,666 \mathrm{mg} / \mathrm{L}$ and cadmium at $38.5 \mathrm{mg} / \mathrm{L}$.

\subsection{Plant Analysis}

Plant samples were harvested every fifteen days after heavy metal treatment. The whole plant was washed thoroughly with running tap water, divided into shoots and roots, and weighed, dried in an oven at $80^{\circ} \mathrm{C}$ for two days and weighed again. Dried plant tissues were cut into small pieces, and homogenized. Approximately $0.1-0.3 \mathrm{~g}$ of shoot and root material were digested in a $3 \mathrm{ml}$ concentration of $\mathrm{HNO}_{3}$ and microwave digestion (CEM model MDS - 2100) for 30 minutes. Samples were evaporated to near dryness, filtered, and adjusted to a volume of $25 \mathrm{ml}$ distilled water. The sample solutions were collected in polypropylene bottles and measured using FAAS, GFAAS, and HG.

\subsection{Water Analysis}

After fifteen days of treatment, $5 \mathrm{ml}$ water samples were collected from the control and the treatment groups. The water samples were adjusted to a volume of $25 \mathrm{ml}$, collected in polypropylene bottles, and analyzed for lead and cadmium using FAAS, GFAAS, and HG.

\subsection{Data Analysis}

Data were analyzed using Excel analysis of variance (ANOVA) for significant differences $(\mathrm{P} \leq 0.05)$. Duncan's New Multiple Range Test was used to determine significant differences $(\mathrm{P} \leq 0.05)$.

\section{Results}

\subsection{Soil and Water Characteristics}

The basic characteristics of the soil used in the soil-water microcosms are presented in Table 1. The results indicate that the soil is a sandy loam typical of many ecosystems. At the end of the experiment, the soil and water were examined in each microcosm for total lead and cadmium.

Table $\mathbf{2}$ and Figures 1 and $\mathbf{2}$ summarized the lead and cadmium concentrations for all soil - water microcosms after 15 days. The results indicated that soil lead levels of Group 4 microcosms were higher than Group 3 microcosms $(1061 \pm 476.6$ as compared to $841.7 \pm 39.82$ $\mathrm{mg} / \mathrm{kg}$ ), but the water lead levels were slightly different, 
Table 1. Physical and chemical characteristics of microcosm soils.

\begin{tabular}{cc}
\hline \multicolumn{2}{c}{ Soil properties } \\
\hline Clay $(\%)$ & $6-18$ \\
Moist bulk density $\left(\mathrm{g} / \mathrm{cm}^{3}\right)$ & $1.3-1.6$ \\
Permeability $(\mathrm{h})$ & $0.6-6.0$ \\
Available water capacity (in) & $0.1-0.16$ \\
Soil $\mathrm{pH}$ & $3.6-6.0$ \\
Organic matter $(\%)$ & $2-6$ \\
Total soil $\mathrm{Pb}(\mathrm{mg} / \mathrm{kg})$ & 8.71 \\
Total soil $\mathrm{Cd}(\mathrm{mg} / \mathrm{kg})$ & 0.38 \\
Total water $\mathrm{Pb}(\mu \mathrm{g} / \mathrm{L})$ & 9.96 \\
Total water $\mathrm{Cd}(\mathrm{mg} / \mathrm{L})$ & $\mathrm{ND}$ \\
\hline
\end{tabular}

ND: Not detected

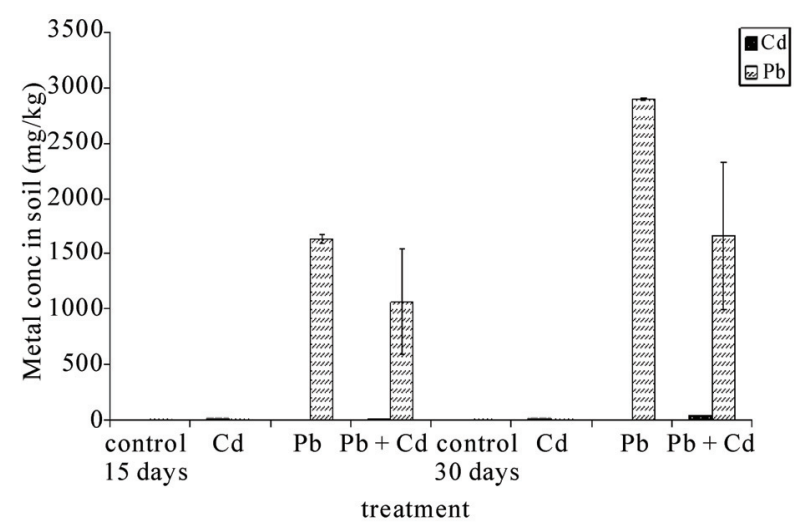

Figure 1. Cadmium and lead concentrations in soil micro$\operatorname{cosms}(\mathbf{m g} / \mathbf{k g})$.

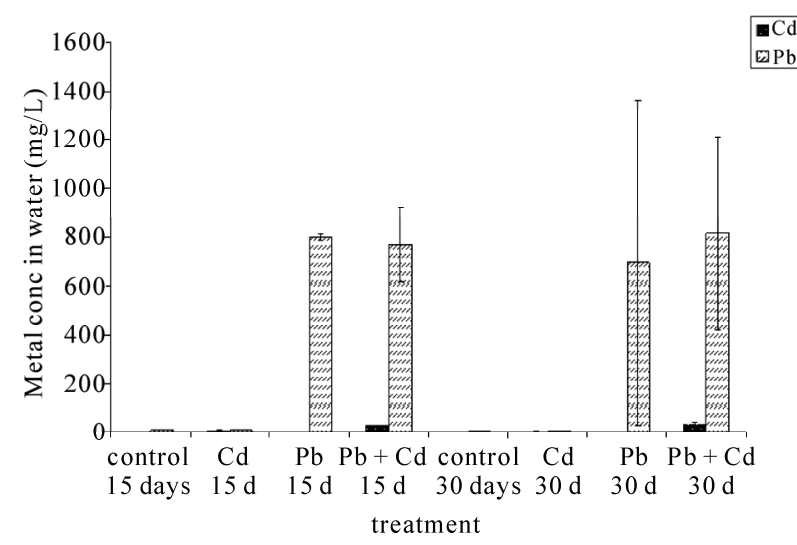

Figure 2. Cadmium and lead concentrations in water microcosm (mg/L). thus there was a significant difference in mean lead in water $(\mathrm{P} \leq 0.05)$. Group 2 microcosms soil cadmium levels were approximately $13 \pm 0.5 \mathrm{mg} / \mathrm{kg}$ as compared to $39.8 \pm 2 \mathrm{mg} / \mathrm{kg}$ in Group 4 microcosms indicating that soil cadmium level increased 3 folds. There was a significant difference in mean lead in soil $(\mathrm{P} \leq 0.05)$. The water cadmium level in Group 4 microcosms $(24.2 \pm 2.6)$ was higher than Group 2 microcosms $(4.8 \pm 1.1)$. There was a significant difference in mean cadmium in water $(\mathrm{P}$ $\leq 0.05)$.

After 30 days, Group 4 microcosms had soil lead levels of approximately $1,658 \pm 663 \mathrm{mg} / \mathrm{kg}$ as compared to $998 \pm 11 \mathrm{mg} / \mathrm{kg}$ in Group 3 microcosms and the soil lead level in Group 4 microcosms was higher than Group 3 microcosms. The water lead level in Group 4 microcosms $(814.8 \pm 396.2)$ was higher than Group 3 microcosms $(697.4 \pm 668.9)$. Cadmium accumulation in soil decreased when lead was added to the soil $(14.3 \pm 1.3$ as compared to $6.5 \pm 0.6 \mathrm{mg} / \mathrm{kg}$ ). There was a significant difference in mean cadmium in soil $(\mathrm{P} \leq 0.05)$. Group 4 microcosm water cadmium levels were $28.6 \pm 11.8 \mathrm{mg} / \mathrm{L}$ as compared to $1.3 \pm 0.6$ in Group 2 microcosm water. The statistical trends suggested interaction effects between the two metals as increased soil lead concentrations and decreased soil cadmium concentrations.

\subsection{T. Angustifolia Growth Characteristics}

The growth patterns of $T$. angustifolia expressed as fresh and dry weights are summarized in Table 3 and Figures 3 and 4. Statistical trends indicated increased biomass over time in all contaminated and control soil microcosm. The lead and cadmium nitrate salts used as contaminants most likely explain the differences in control and experimental biomass. However, mean fresh and dry weights were not significantly different between treatment groups $(\mathrm{P}>0.05)$ over the 30 day exposure period (Figures 3 and 4). Interestingly, in Group 3 and 4 the fresh and dry weight of shoot biomass increased while those of root biomass seem to unchanged (Figures 3 and 4). Group 2 plants had trends with increased fresh and dry weight shoot and root biomass.

\subsection{Lead and Cadmium Accumulation in Plant Biomass}

Concentrations of lead and cadmium in T. angustifolia shoot and root biomass are summarized in Table $\mathbf{4}$ and Figures 5 and 6. The results on both 15 and 30 day treatments indicated that there was a lead and cadmium interaction which resulted in a marked reduction in lead uptake and a slight decrease in cadmium uptake by $T$. angustifolia.

Lead levels in shoot and root biomass in the combined 
Table 2. Lead and cadmium concentrations in soil - water microcosms.

\begin{tabular}{|c|c|c|c|c|c|}
\hline \multirow{2}{*}{ Time } & \multirow{2}{*}{ Treatment (group) } & \multicolumn{2}{|c|}{ Soil $(\mathrm{mg} / \mathrm{kg})^{\mathrm{a}}$} & \multicolumn{2}{|c|}{ Water $(\mathrm{mg} / \mathrm{L})^{\mathrm{a}}$} \\
\hline & & Cd & $\mathbf{P b}$ & Cd & $\mathbf{P b}$ \\
\hline \multirow{4}{*}{15 days } & 1 (control) & ${ }^{\mathrm{b}} 0.1 \pm 0$ & ${ }^{\mathrm{h}} 6.3 \pm 0.7$ & ${ }^{1} \mathrm{ND}$ & $\mathrm{p}, * 8 \pm 0.7$ \\
\hline & $2(\mathrm{Cd})$ & ${ }^{\mathrm{c}} 13 \pm 0.5$ & ${ }^{\mathrm{h}} 10.3 \pm 0$ & ${ }^{1} 4.8 \pm 1.1$ & $\mathrm{p}, * 7.5 \pm 0.5$ \\
\hline & $3(\mathrm{~Pb})$ & ${ }^{\mathrm{b}} 0.1 \pm 0.1$ & ${ }^{\mathrm{h}} 841.7 \pm 39.8$ & ${ }^{1, *} 0.3 \pm 0.1$ & ${ }^{\mathrm{q}} 800 \pm 12.5$ \\
\hline & $4(\mathrm{~Pb}+\mathrm{Cd})$ & ${ }^{\mathrm{d}} 39.8 \pm 2$ & ${ }^{\mathrm{i}} 1061.3 \pm 476.6$ & $\mathrm{~m}_{24.2} \pm 2.6$ & ${ }^{\mathrm{q}} 770 \pm 149.2$ \\
\hline \multirow{4}{*}{30 days } & 1 (control) & ${ }^{\mathrm{e}} 0.1 \pm 0$ & ${ }^{\mathrm{j}} 5.2 \pm 0.1$ & ${ }^{\mathrm{n}, *} 0.4 \pm 0.2$ & $\mathrm{r}, * 4.6 \pm 0.3$ \\
\hline & $2(\mathrm{Cd})$ & ${ }^{\mathrm{f}} 14.3 \pm 1.3$ & ${ }^{\mathrm{j}} 5.1 \pm 0.1$ & ${ }^{\mathrm{n}} 1.3 \pm 0.6$ & $\mathrm{r}, * 2.5 \pm 0.5$ \\
\hline & $3(\mathrm{~Pb})$ & ${ }^{\mathrm{e}} 0.1 \pm 0.1$ & ${ }^{\mathrm{j}} 997.6 \pm 11.4$ & ${ }^{\mathrm{n}}, * 0.3 \pm 0.1$ & ${ }^{\mathrm{r}} 697.4 \pm 668.9$ \\
\hline & $4(\mathrm{~Pb}+\mathrm{Cd})$ & ${ }^{\mathrm{g}} 6.5 \pm 0.6$ & ${ }^{\mathrm{k}} 1657.6 \pm 663.2$ & ${ }^{\circ} 28.6 \pm 11.8$ & ${ }^{\mathrm{r}} 814.8 \pm 396.2$ \\
\hline
\end{tabular}

${ }^{*} \mu \mathrm{g} / \mathrm{L} ;{ }^{a}$ values are means from 2 replications with standard error $(\mathrm{n}=2) ;{ }^{\mathrm{b}, \mathrm{c}, \mathrm{h}}$ homogeneous subsets of soil cadmium in 15 days; ${ }^{\mathrm{e}, \mathrm{f}, \mathrm{g}}$ homogeneous subsets of soil cadmium in 30 days; ${ }^{\text {hi }}$ homogeneous subsets of soil lead in 15 days; ${ }^{j, k}$ homogeneous subsets of soil lead in 30 days; ${ }^{1, m}$ homogeneous subsets of water cadmium in 15 days; ${ }^{\mathrm{n}, \mathrm{o}}$ homogeneous subsets of water cadmium in 30 days; ${ }^{\mathrm{p}, \mathrm{q}}$ homogeneous subsets of water cadmium in 15 days; ${ }^{\mathrm{r}}$ homogeneous subsets of water cadmium in 30 days.

Table 3. Fresh and dry weight in shoot and root biomass of $T$. angustifolia in contaminated soil-water microcosms.

\begin{tabular}{|c|c|c|c|c|c|}
\hline \multirow{2}{*}{ Time } & \multirow{2}{*}{ Treatment (group) } & \multicolumn{2}{|c|}{ Fresh weight $(g)^{a}$} & \multicolumn{2}{|c|}{ Dry weight $(g)^{a}$} \\
\hline & & Shoot & Root & Shoot & Root \\
\hline \multirow{4}{*}{15 days } & 1 (control) & $23.9 \pm 2.2$ & $22.3 \pm 1$ & $2.2 \pm 0.2$ & $2.3 \pm 0$ \\
\hline & $2(\mathrm{Cd})$ & $26.7 \pm 11.4$ & $12 \pm 5.3$ & $2.5 \pm 1.2$ & $1.6 \pm 0.4$ \\
\hline & $3(\mathrm{~Pb})$ & $35.7 \pm 19.9$ & $11.1 \pm 5.1$ & $3.2 \pm 1.8$ & $1.6 \pm 0.3$ \\
\hline & $4(\mathrm{~Pb}+\mathrm{Cd})$ & $48.4 \pm 14.3$ & $22.5 \pm 2$ & $5 \pm 1.4$ & $2.3 \pm 0.1$ \\
\hline \multirow{4}{*}{30 days } & 1 (control) & $37.3 \pm 11.3$ & $25.7 \pm 4.7$ & $4.1 \pm 1.3$ & $1.8 \pm 0.2$ \\
\hline & $2(\mathrm{Cd})$ & $36.5 \pm 5.3$ & $19.5 \pm 7.3$ & $4.1 \pm 0$ & $1.6 \pm 0.4$ \\
\hline & $3(\mathrm{~Pb})$ & $77.6 \pm 26$ & $17.5 \pm 2.1$ & $10.7 \pm 3.5$ & $1.9 \pm 0.3$ \\
\hline & $4(\mathrm{~Pb}+\mathrm{Cd})$ & $75.5 \pm 22.7$ & $24.2 \pm 7.5$ & $10.6 \pm 4.4$ & $2.1 \pm 0.8$ \\
\hline
\end{tabular}

${ }^{\mathrm{a}}$ values are means from 2 replications with standard error $(\mathrm{n}=2)$.

Table 4. Concentration of lead and cadmium in shoot and root biomass of T. angustifolia.

\begin{tabular}{|c|c|c|c|c|c|}
\hline \multirow{2}{*}{ Time } & \multirow{2}{*}{ Treatment (group) } & \multicolumn{2}{|c|}{$\mathrm{Pb}(\mathrm{mg} / \mathrm{kg})^{\mathrm{a}}$} & \multicolumn{2}{|c|}{$\mathrm{Cd}(\mathrm{mg} / \mathrm{kg})^{\mathrm{a}}$} \\
\hline & & Shoot & Root & Shoot & Root \\
\hline \multirow{4}{*}{15 days } & 1 (control) & ${ }^{\mathrm{b}} 2.8 \pm 1.8$ & ${ }^{\mathrm{f}} 6.6 \pm 2.3$ & ${ }^{\mathrm{j}} \mathrm{ND}$ & ${ }^{\mathrm{m}} 0.6 \pm 0.1$ \\
\hline & $2(\mathrm{Cd})$ & ${ }^{\mathrm{b}} 3 \pm 0.4$ & ${ }^{\mathrm{f}} 6.1 \pm 0.1$ & ${ }^{\mathrm{j}} 42.3 \pm 14.9$ & ${ }^{\mathrm{n}} 378.3 \pm 141.5$ \\
\hline & $3(\mathrm{~Pb})$ & ${ }^{\mathrm{c}} 1,875.9 \pm 663.6$ & $\mathrm{~g}_{22,462 \pm 2,804.6}$ & ${ }^{\mathrm{j}} 0.7 \pm 0.4$ & ${ }^{\mathrm{m}} 0.6 \pm 0.2$ \\
\hline & $4(\mathrm{~Pb}+\mathrm{Cd})$ & ${ }^{\mathrm{b}} 529.3 \pm 57.8$ & ${ }^{\mathrm{g}} 16,555 \pm 2,854.5$ & $\mathrm{j}_{33.5} \pm 24.7$ & $\mathrm{~m}, \mathrm{n} 223.3 \pm 18.7$ \\
\hline \multirow{4}{*}{30 days } & 1 (control) & ${ }^{\mathrm{d}} 1.2 \pm 0.2$ & $\mathrm{~h}_{3.4} \pm 0.2$ & ${ }^{\mathrm{k}} 0.1 \pm 0$ & ${ }^{\circ} 0.8 \pm 0.1$ \\
\hline & $2(\mathrm{Cd})$ & ${ }^{\mathrm{d}} 1.1 \pm 0.5$ & ${ }^{\mathrm{h}} 4 \pm 0$ & $\mathrm{l} 20.3 \pm 2.6$ & ${ }^{\mathrm{o}, \mathrm{p}} 241 \pm 119.5$ \\
\hline & $3(\mathrm{~Pb})$ & ${ }^{\mathrm{e}} 354.9 \pm 22.3$ & ${ }^{\mathrm{i}} 20,173.6 \pm 2,165.6$ & ${ }^{\mathrm{k}} 0.4 \pm 0.2$ & ${ }^{\circ} 1.5 \pm 0.7$ \\
\hline & $4(\mathrm{~Pb}+\mathrm{Cd})$ & ${ }^{\mathrm{e}} 404.3 \pm 21.1$ & ${ }^{\mathrm{i}} 13,675 \pm 3,925$ & ${ }^{1} 20.5 \pm 1.9$ & ${ }^{\mathrm{p}} 369.2 \pm 82.3$ \\
\hline
\end{tabular}

${ }^{a}$ values are means from 2 replications with standard error $(n=2) ;{ }^{b, c}$ homogeneous subsets of lead in shoot in 15 days; ${ }^{\text {de }}$ homogeneous subsets of lead in shoot in 30 days; ${ }^{\mathrm{f} g}$ homogeneous subsets of lead in root in 15 days; ${ }^{\text {h,i }}$ homogeneous subsets of lead in root in 30 days; ${ }^{j}$ homogeneous subsets of cadmium in shoot in 15 days; ${ }^{\mathrm{k}, \mathrm{l}}$ homogeneous subsets of cadmium in shoot in 30 days; ${ }^{\mathrm{m}, \mathrm{n}}$ homogeneous subsets of cadmium in root in 15 days; ${ }^{\mathrm{o}, \mathrm{p}}$ homogeneous subsets of cadmium in root in 30 days. 


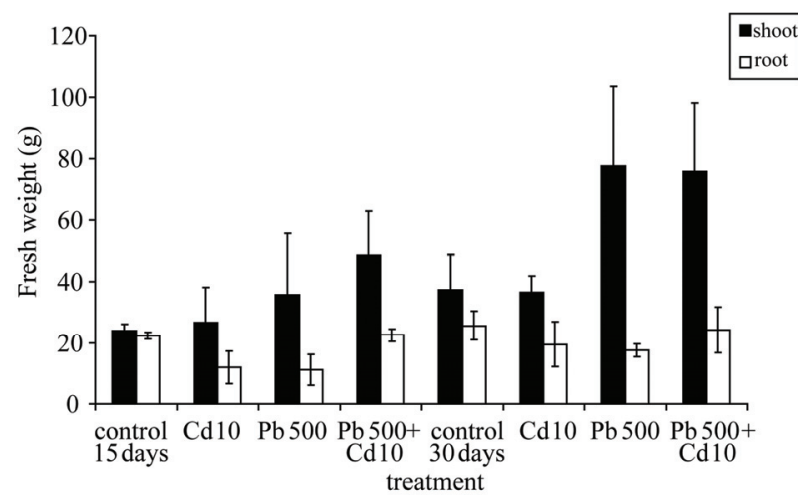

Figure 3. Biomass fresh weight (shoots and roots) (g).

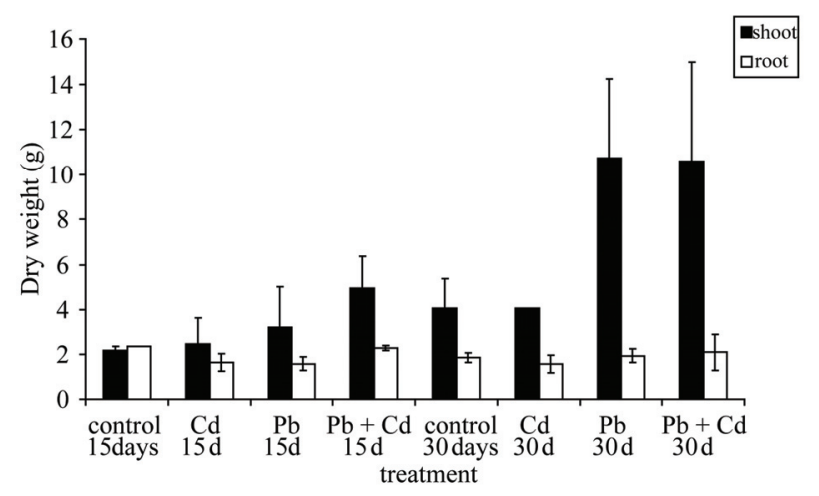

Figure 4. Biomass dry weight (shoots and roots) (g).

lead and cadmium microcosms decreased approximately two and one fold after 15 days of treatment Group 4 $(529.3 \pm 57.8)$ as compared to Group $3(1,875.9 \pm$ 663.6)). There was a significant difference $(\mathrm{P} \leq 0.05)$ in mean shoot and root lead accumulation of T. angustifolia at day 15. After 30 days, lead accumulation in shoot biomass of Group 4 was slightly higher than that of Group 3 (404.3 \pm 21.1 as compared to $354.9 \pm 22.3$ $\mathrm{mg} / \mathrm{kg}$ ). In root biomass, lead concentration was lower in Group 4 as compared to Group $3(13,675 \pm 3,925$ vs $20,173.6 \pm 2,165.6 \mathrm{mg} / \mathrm{kg}$ ). There was a significant difference $(\mathrm{P} \leq 0.05)$ in mean shoot and root lead accumulation of T. angustifolia in 30 days (Figure 5).

Cadmium uptake in shoot biomass decreased when lead was added to the soil in 15 days (Table 4) (Group 4 compared to Group 2). There was no significant difference $(P>0.05)$ in mean shoot but there was a significant difference in mean root cadmium accumulation of $T$. angustifolia in 15 days. After 30 days, cadmium uptake in root biomass increased when lead was added to the soil (Group 4 compared to Group 2). There was a significant difference $(\mathrm{P} \leq 0.05)$ in the mean shoot but there was no significant difference in mean root cadmium accumulation of $T$. angustifolia biomass in 30 days (Figure

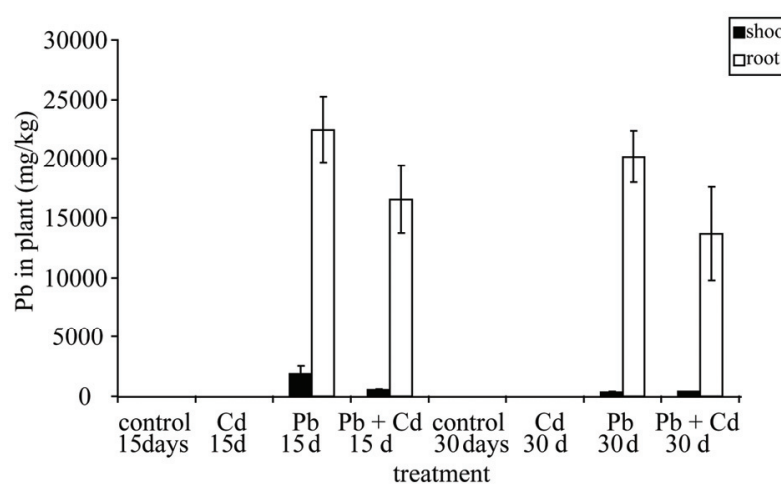

Figure 5. Concentration of lead in shoot and root biomass $(\mathrm{mg} / \mathrm{kg})$.

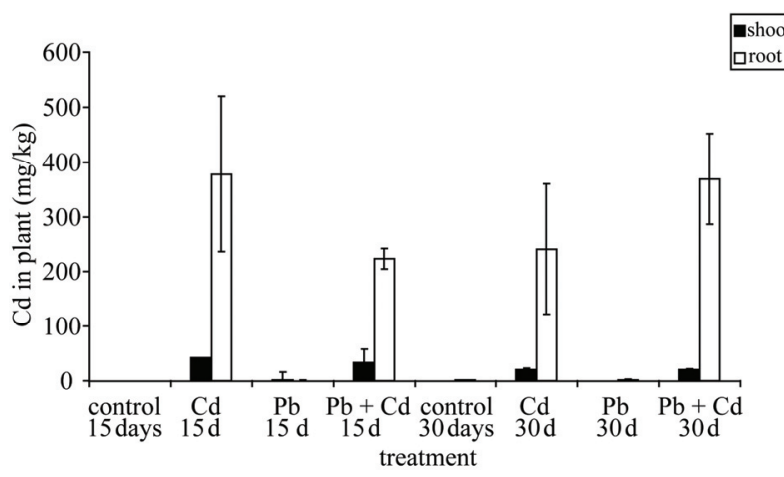

Figure 6. Concentration of cadmium in shoot and root biomass (mg/kg).

6). The statistical trends suggested interaction effects with cadmium inhibiting lead uptake in both roots and shoots.

\section{Discussion}

In this study, lead treatments did not affect fresh or dry weights of T. angustifolia. Plants growing in microcosms with lead contaminated soils grew as well or better than plants in control microcosms. Cadmium treatment plants had fresh weight of shoot biomass similar to controls. It is possible that cadmium could be taken up by the roots and transported by the xylem to the vegetative and reproductive organs, negatively affecting plant health [8]. Plants could also accumulate high quantities of cadmium without suffering adverse effects on growth [9].

In the present study, increasing cadmium input to soil microcosm highly increased cadmium accumulation in shoot biomass and hence inhibited cadmium accumulation in root biomass. This is in agreement with the finding by Cunningham et al. [10] Plants grew well in the lead and cadmium contaminated soils in this study, however accumulated lower concentrations of lead a 
30-day growth period.

Coughtrey and Martin [11] studied Midger plant (Holcus lanatus) uptake of cadmium, lead, and zinc in solution culture and showed interactions on lead concentrations in roots. Interestingly, the significant effects in shoots of this population were positive and tend towards increased metal concentrations. Miller et al. [12] reported positive interactions between lead and cadmium on lead and cadmium uptake in corn roots. Moshe et al. [13]. demonstrated that low levels $(<1 \mathrm{mg} / \mathrm{L})$ of lead increased the toxicity of cadmium $(0.1 \mathrm{mg} / \mathrm{L})$ in phytoplankton. Antagonism occured when the concentration of lead exceeded that of cadmium but no synergistic effects were noted in Chlorella when cadmium, copper, chromium, and nickel were added to the culture media. Pretreatment of algae with nickel and mercury reduced cadmium toxicity; this may reflect competition among metals for cellular binding sites.

The results of this study provide evidence for phytoextraction interactions of lead and cadmium in soil-water microcosms. The statistical trends suggested that the interaction is complex and produced, decreased lead in root biomass and increased cadmium in shoot biomass although there were no significant variations in biomass production. Chukwuma [14] compared the accumulation of cadmium, lead, and zinc in cultivated and wild plant species in a derelict lead - zinc mine and found an overall reduction in the potential toxicity of cadmium by zinc through simple mass action effects specific for cultivated plants, they noted that other additional tolerant or adaptive mechanisms might be operative in the wild plants. McKena et al. [15] reported the interactions between zinc and cadmium in nutrient solution and their effects on the accumulation of both metals in plant roots and leaves and also reported higher cadmium concentrations in older compared to younger leaves of lettuce and spinach.

Many other studies involving several metals and nutrients have been reported. Lagerwerff and Biersdorf [16] reported that cadmium and zinc were competitive cations. Similarly, Robert et al. [17] showed that cadmium can functionally substitute for zinc. The changes in the iron and zinc concentrations induced by increased cadmium levels resulted in alterations of the iron/zinc ratio and the alteration was more pronounced in roots than shoots, with both tissues exhibiting increases in the iron/zinc ratio with increased concentrations of cadmium. On the contrary, the toxicity of cadmium has been linked to the fact that cadmium competes for similar active sites but does not functionally substitute for zinc [18].

Cadmium and lead are toxic heavy metals and zinc an essential element makes this association interesting as it raises the possibility that the toxic effects of cadmium may be preventable or treatable by zinc. Hinesly et al. [19] indicated that both cadmium and zinc uptake by plants were dependent on the $\mathrm{pH}$ of the growing media. Ravera [20] showed that cadmium had toxic effects in plants on photosynthesis and also indicated various changes in biological activities. Subsequent studies have confirmed these findings and extended the interaction to other toxic effects of cadmium like inhibition of cell proliferation, and cytotoxic action [21] and growth suppression in plants [22].

The biochemical mechanisms of cadmium - zinc interaction are unknown, but various cellular and subcellular processes like the ratio of the cadmium to zinc in the tissues, induction of synthesis of different types of metallothionein, alteration of absorption and tissue distribution of one metal by another, and competition at the level of zinc containing metalloenzymes are known to be involved in the interaction [23]. Minnie et al. [24] studied phytoextraction of soil cobalt using hyperaccumulator plants and found interaction and decreased uptake of nickel in the presence of cobalt. Homer et al. [25] also reported that the uptake of cobalt may suppress nickel uptake, indicating a possible synergistic or antagonistic relationship between the elements.

\section{Conclusions}

T. angustifolia exhibited very good potential for the phytoextraction of mixtures of lead and cadmium contaminants from soil-water microcosms. Although cadmium interaction appeared to reduce the uptake of lead in soil-water microcosms contaminated with both metals, uptake of lead into T. angustifolia roots was high, reaching levels of $13,675 \pm 3,925 \mathrm{mg} / \mathrm{kg}$ after 30 days growth.

\section{Acknowledgements}

This work was supported by the Thailand Research Fund. We thank Dr. Wipharat Chuachuad for analyzing the samples.

\section{REFERENCES}

[1] M. Baghour, A. M. Diego, V. Gemma, H. Joaquin, C. Nicolas and R. Luis, "Phytoextraction of Cadmium and Lead and Physiological Effects in Potato Plants (Solanum tuberosum var. Spunta): Importance of Root Temperature," Journal of Agriculture Food Chemistry, Vol. 49, No. 11, 2001, pp. 5356-5363.

[2] F. Fodor, E. Cseh, A. Varga and G. Zaray, "Lead Uptake, Distribution, Remobilization in Cucumber," Journal of Plant Nutrition, Vol. 21, No. 7, 1998, pp. 1363-1373.

[3] M. Z. Iqbal, M. Rukhsana and S. Muhammad, "The Effect of Lead and Cadmium on Trees," Journal of Soc. Munic. Arb., Vol. 36 No. 1, 2000, pp. 1-2. 
[4] R. Kastori, M. Plesnicar, Z. Sakac, D. Pankovic and I. Arsenijevicmaksimovic, "Effect of Excess Lead on Sunflower Growth and Photosynthesis," Journal of Plant Nutrition, Vol. 21, No. 1, 1998, pp. 75-85.

[5] E. H. Larron, J. F. Bornman and H. Asp, "Influence of UV B Radiation and $\mathrm{Cd}^{2+}$ an Chlorophyll Fluorescence, Growth and Nutrient Content in Brassica napus," Journal of Experimental Botany, Vol. 49, No. 323, 1998, pp. 10311039.

[6] B. S. Mohan and B. B. Hosetti, "Potential Phytotoxicity of Lead and Cadmium to Lemna Minor Grown in Sewage Stabilization Ponds," Environmental Pollution, Vol. 98, No. 3, 1997, pp. 233-238.

[7] M. Wierzbicka, "Lead in the Apoplast of Allium Cepa L. root Tips-Ultrastructural Studies," Plant Science, Vol. 133, No. 1, 1998, pp. 105-119.

[8] A. Stroinski, "Some Physiological and Biochemical Aspects of Plant Resistance to Cadmium Effect. I. Antioxidative System," Acta Psychologica, Vol. 21, No. 1, 1999, pp. 175-188.

[9] A. Kabata-Pendias and H. Pendias, "Trace Elements in Soil and Plants," CRC Press, Boca Raton, 1992.

[10] L. M. Cunningham, F. W. Collins and T. C. Hutchinson, "Physiological and Biochemical Aspects of Cadmium Toxicity in Soybean," In: Proceedings of International Conference Heavy Metals in the Environment, Toronto, 1975.

[11] P. J. Coughtrey and M. H. Martin, "Cadmium, Lead, and Zinc Interactions and Tolerance in Two Populations of Holcus lanatus L. Grown in Solution Culture," Environmental and Experimental Botany, Vol. 19, 1979, pp. 285-290 .

[12] J. E. Miller, J. J. Hassett and D. E. Koeppe, "Interactions of Lead and Cadmium on Metal Uptake and Growth of Corn Plants," Journal of Environmental Quality, Vol. 6, No. 3, 1977, pp. 18-20.

[13] M. Moshe, N. Betzer and Y. Kott, "Effect of Industrial Wastes on Oxidation Pond Performance," Water Resources, Vol. 6, 1972, pp. 1165-1171.

[14] C. Chukwuma Sr, "Comparison of the Accumulation of Cadmium, Lead and Zinc in Cultivated and Wild Plant Species in the Derelict Enyigba Lead-zinc Mine," Toxicological and Environmental Chemistry, Vol. 38, No. 3$-4,1993$, pp. 167-173.
[15] I. M. McKenna, R. L. Chaney and F. M. Williams, "The Effects of Cadmium and Zinc Interactions on the Accumulation and Tissue Distribution of Zinc and Cadmium in Lettuce and Spinach," Environment Pollution, Vol. 79, No. 2, 1993, pp. 113-120.

[16] J. V. Lagerwerff and G. T. Biersdorf, "Interaction of Zinc with Uptake and Translocation of Cadmium in Radish," Proceedings 5th Annual Conference on Trace Substances on Environmental Health, University of Missouri, Columbia, 1972, pp. 515-522.

[17] A. R. Robert, J. M. Raymond and D. E. Koeppe, "Uptake of Cadmium - Its Toxicity, and Effect on the Iron Ratio in Hydroponically Grown Corn," Journal of Enviromental Quality, Vol. 4, No. 1, 1975, pp. 473-476.

[18] R. E. Vallee and D. D. Ulmer, "Biochemical Effects of Mercury, Cadmium, and Lead," Annual Review of Biochemistry, Vol. 40, No. 10, 1972, pp. 91-128.

[19] T. D. Hinesly, K. E. Redberg, R. I. Pietz and E. L. Ziegler, "Cadmium and Zinc Uptake by Corn (Zea mays L.) with Repeated Applications of Sewage Sludge," Journal of Agricultural and Food Chemistry, Vol. 32, 1984, pp. 155-163.

[20] O. Ravera, "Cadmium in Freshwater Ecosystems," Experientia, Vol. 40, No. 5, 1984, pp. 1-14.

[21] I. Rosas, M. E. Carbajal, S. Gomez-Arroyo, R. Belmont and R. Villalogos-Pietrini, "Cytogenetic Effects on Cadmium Accumulation on Water Hyacinth (Eichornia crassipes)," Environment Resarch, Vol. 33, No. 3, 1984, pp. 386-395.

[22] R. L. Chaney, M. C. White and P. W. Simon, "Plant Uptake of Heavy Metals from Sewage Sludge Applied to Land," Proceeding of Iind National Conference Municipal Sludge Management, Rockville, 1975, pp. 167-178.

[23] P. Das, S. Samantaray and G. R. Rout, "Studies on Cadmium Toxicity in Plants: a Review," Environmental Pollution, Vol. 98, No. 1, 1997, pp. 29-36.

[24] M. Minnie, L. C. Rufus, P. B. Eric, Y.-M. Li and J. S. Angle, "Phytoextraction of Soil Cobalt Using Hyperaccumulator Plants," International Journal of Phytorem, Vol. 2, No. 4, 2000, pp. 319-329.

[25] F. A. Homer, R. S. Morrison, R. R. Brook, J. Clemens and R. D. Reeves, "Comparative Studies of Ni, Co, and $\mathrm{Cu}$ Uptake by Some Ni Hyperaccumulators of the Genus Alyssum," Plant Soil, Vol. 138, 1999, pp. 195-205. 